\title{
Pengembangan Buku Ajar Evaluasi Pembelajaran Anak Usia Dini Bermuatan Nilai Karakter Tri Kaya Parisudha Dengan Strategi Think Talk Write
}

\author{
I Ketut Suparya ${ }^{1}$, I Gede Arya Wiradnyana², Komang Agus Budhi Arya Pramana ${ }^{3}$, \\ Ni Luh Ika Windayani ${ }^{4}$, Ni Wayan Risna Dewi ${ }^{5}$ \\ ${ }^{12345}$ Sekolah Tinggi Agama Hindu Negeri Mpu Kuturan Singaraja \\ 1iketutsuparya@gmail.com, 2arya.wiradnyana92@gmail.com, \\ ${ }^{3}$ mangagus460@gmail.com, ${ }^{4}$ windayaniika3@gmail.com, ${ }^{5}$ risnadw92@gmail.com
}

\begin{abstract}
The purposes of this study are (1) to describe the feasibility of evaluating early childhood learning textbooks containing the Tri Kaya Parisudha character with a think talk write strategy developed in terms of content and construct validity, (2) to describe the feasibility of early childhood learning evaluation textbooks containing characters. Tri Kaya Parisudha with a think talk write strategy which was developed in terms of practical use in the classroom. This research is a Research and Development (R\&D) model or research and development. Research and development is a process or scientific steps used in researching, producing or improving existing products. This development refers to the model of the Borg and Gall measures. The data that has been obtained using an instrument that has been designed and then analyzed descriptively with qualitative descriptive techniques. The quality of the product in the form of teaching materials developed must meet the feasibility of the aspects of validity and practicality. From the results of research data analysis, the conclusions of this study are as follows: (1) early childhood learning evaluation textbooks containing the value of the tri Kaya Parisudha character with thik talk write settings have met the feasibility of content validity with a score of 4.52 being in the very good category, (2) early childhood learning evaluation textbooks containing the value of the tri Kaya parisudha character with the thik talk write setting have met the practicality seen from the aspect of using time which is classified as efficient, and the student score of 3.72 is in the good category.
\end{abstract}

Keywords: Textbook; Character; Tri Kaya Parisudha; Think Talk Write

\begin{abstract}
Abstak
Tujuan dari penelitian ini adalah (1) mendeskripsikan kelayakan buku ajar evaluasi pembelajaran anak usia dini bermuatan karakter tri kaya parisudha dengan strategi think talk write yang dikembangkan dari segi validitas isi dan konstruk, (2) mendeskripsikan kelayakan buku ajar evaluasi pembelajaran anak usia dini bermuatan karakter tri kaya parisudha dengan strategi think talk write yang dikembangkan dari segi kepraktisan penggunaan di kelas. Penelitian ini merupakan model Research and Development $(R \& D)$ atau penelitian dan pengembangan. Penelitian dan pengembangan merupakan proses atau langkah-langkah ilmiah yang digunakan dalam meneliti, memproduksi atau menyempurnakan produk yang telah ada. Pengembangan ini mengacu pada model dari langkah-langkah Borg and Gall. Data yang telah didapatkan dengan menggunakan instrumen yang telah dirancang kemudian dianalisis secara deskriptif dengan teknik deskriptif kualitatif. Kualitas produk berupa bahan ajar yang dikembangkan harus memenuhi kelayakan dari aspek validitas dan kepraktisan. Dari hasil analisis data
\end{abstract}


penelitian, simpulan penelitian ini adalah sebagai berikut: (1) buku ajar evaluasi pembelajaran anak usia dini bermuatan nilai karakter tri kaya parisudha dengan setting thik talk write telah memenuhi kelayakan validitas isi dengan skor 4,52 berada pada kategori sangat baik, (2) buku ajar evaluasi pembelajaran anak usia dini bermuatan nilai karakter tri kaya parisudha dengan setting thik talk write telah memenuhi kepraktisan dilihat dari aspek penggunaan waktu yang tergolong efesien, serta skor siswa yang yaitu sebesar 3,72 berada pada kategori baik.

\section{Kata Kunci: Buku Ajar; Karakter; Tri Kaya Parisudha; Think Talk Write}

\section{Pendahuluan}

Penyiapan sumber daya manusia yang cerdas dan berkarakter merupakan salah satu pilar dalam menopang pembangunan bangsa Indonesia yang sejalan dengan tujuan pendidikan nasional (Adnyana, 2017). Pasal 1 Undang-undnag No 20 tahun 2003 menyebutkan bahwa salah satu tujuan pendidikan Indonesia adlaah untuk membentuk dan mengembangkan seluruh potensi yang dimiliki oleh anak untuk menjadikan anak tersebur memiliki karakter beriman dan bertaqwa kepada Tuhan Yang Maha Esa, berahklak mulia, sehat, berilmu, cakap, kreatif, mandiri, dan menjadi warga Negara yang demokratis serta bertanggung jawab. Berdasarkan hal tersebut mencerminkan bahwa pendidikan yang dilangsungkan di Indonesia untuk seluruh jenjang pendidikan termasuk di dalamnya pada jenjang perguruan tinggi harus diselenggarkan secara sistematis serta diharapkan mampu membentuk karakter peserta didik sehingga nantinya mampu bersaing, beretika, bermoral, memiliki rasa sopan santun dalam pergaulan di masyarakat.

Salah satu tujuan yang diharapkan dalam proses pendidikan adalah meningkatkan karakter siswa Indonesia seutuhnya. Terkait dengan pembentukan karakter secara nasioanl menunjukkan masih jauh dari tujuan pendidikan nasional, karena pembelajaran yang dilakukan selama ini masih berfokus pada ranah kognitif dengan lebih banyak mengembangkan kemampuan pengetahuan intelligence quotient (IQ) tanpa diimbangi dengan pengembangan kemampuan emotional quotient (EQ), dan spiritual quotient (SQ). Rendahnya karakter peserta didik tercermin dari tayangan televisi seperti tawuran pelajar, tawuran mahasiswa, demonstrasi anarkis, pengerusakan lingkungan, kekerasan, kerusuhan, korupsi yang merambah disemua sektor. Pendidikan karakter akan mampu membentuk, menanamkan serta memfasilitasi serta mengembangkan nilai-nilai positif pada anak guna menjadikan pribadi unggul dan bermartabat.

Proses pendidikan yang baik harus dimulai sejak jenjang pendidikan anak usia dini sampai dengan tingkat perguruan tinggi. Proses pembelajaran yang baik serta dibarengi dengan pembentukan karakter akan mampu membangun generasi yang cerdas dan berkarakter. Salah satu alternatif strategi pembelajaran yang diduga mampu membentuk generasi cerdas dan berkarakter adalah mengembangkan model pembelajaran karakter berbasis kearifan lokal. Salah satu kearifan lokal hindu yang bersifat universal serta dapat digunakan sebagai landasan pendidikan karakter adalah kearifan lokal Tri Kaya Parisudha (Parmajaya, 2018). Tri Kaya Parisudha memiliki makna tiga perbuatan baik yang disucikan yang terdiri dari kayika (berbuat baik), wacika (berkata baik), manacika (berpikir yang baik).

Kearifan lokal Tri Kaya Parisudha diharapkan akan mampu membentuk karakter baik (good character) karan mengandung karekater berpikir baik (Manacika), berkata baik (Wacika) dan berbuat baik (Kayika). Lichona (1991) menyatakan bahwa pembentukan karakter baik akan melibatkan pengetahuan moral (moral knowing), perasaan moral (moral feeling), dan tindakan moral (moral acting). Pembentukan karakter inti Tri Kaya Parisudha di sekolah sangat penting. Hal ini sesuai pendapat Puja (1981); Lodra, (2006 
yang menguraikan bahwa Tri Kaya Parisudha mempunyai tujuan umum seperti berikut: a) untuk mengembangkan sifat dan sikap jujur dan setia dalam berpikir, berkata maupun berbuat bagi peserta didik dan masyarakat pada umumnya, b) untuk menumbuh kembangkan sikap mental yang bertanggung jawab tanpa diawasi oleh orang lain, c) untuk menumbuhkan kesadaran guna berbuat baik dan mengenal berbagai akibat yang dapat timbul dari pikiran, perkataan dan perbuatan yang dilakukan, d) untuk memberi petunjuk yang baik dan perlu dimiliki serta disadari dalam bergaul, sehingga dapat menyesuaikan diri dengan lingkungan, e) untuk mengajarkan agar manusia selalu waspada dan hati-hati terhadap pikiran, perkataan dan perbuatan.

Berkaitan dengan pembentukan pengetahuan moral (moral knowing), perasaan moral (moral feeling), dan tindakan moral (moral acting) dalam upaya membentuk karakter berbasis kearifan lokal Tri Kaya Parisudha, Program Studi Pendidikan Guru Pendidikan Anak Usia Dini (PG PAUD) Sekolah Tinggi Agama Hindu Negeri Mpu Kuturan Singaraja telah merancang serta memberlakukan kurikulum Kerangka Kualifikasi Nasional Indonseia (KKNI) pada seluruh mata kuliah yang ditawarkan kepada mahasiswanya. Menurut Permendikbud No.49/2014, KKNI adalah penjenjangan kualifikasi kompetensi dengan mengintegrasikan antara bidang pendidikan dan pelatihan kerja dalam rangka pemberian pengakuan kompetensi kerja di berbagai sektor. Dengan diberlakukannya kurikulum KKNI diharapkan akan mampu mencetak lulusan yang siap menghadapi millennium development goals atau era globalisasi.

Dalam kurikulum PG PAUD ada salah satu mata kuliah yang bernama evaluasi pendidikan anak usia dini. Mata kuliah ini mengkaji tentang penilaian pendidikan anak usia dini yang terdiri dari keterampilan untuk mengakses perkebambangan anak usia dini yang meliputi perkembangan nilai agama serta moral, fisik/ motorik, kognitif, bahasa, seni dan sosial emosional anak usia dini. Banyaknya bahan materi pada mata kuliah ini menuntut dosen untuk menerapkan pendidikan yang tepat serta diharakan mampu memfasilitasi mahasiswa dalam proses pendidikan sehingga kompetensi mata kuliah bisa tercapai. Terbatasnya media serta sumber belajar mata kuliah evaluasi pendidikan anak usia dini membuat proses pembelajaran menjadi kurang maksimal. Aktivitas pembelajaran yang dilaksanakan selama ini dengan memberikan topik- topik perkuliahan kepada tiap kelompok mahasiswa. Akan tetapi pada pertemuan awal, dosen menerangkan satu topik untuk memberikan pengantar tentang mata kuliah ini. Setelah itu, pembahsan materi diberikan kepada masing-masing kelompok dimana anggota tiap kelompok terdiri atas 23 orang mahasiswa. Kelompok mahasiswa yang akan mempresentasikan materi presentasi ditetapkan sesuai dengan urutan materi dalam kontrak perkuliahan. Indikator penilaian antara lain kemampuan dalam pemecahan permasalahan, keahlian mempresentasikan serta kemampuan mempertahankan topik yang dibahas, dan hasil UTS serta UAS.

Makalah yang terbuat oleh tiap kelompok mahasiswa mencerminkan bahwa mahasiswa kurang terampil menganalisis sesuatu kasus. Mahasiswa hanya menggunakan satu refrensi sebagai sumber kajian karena terbatasnya dalam memperoleh rujukan lain untuk memperkaya pembahasannya dalam makalah. Dampaknya, materi yang terbuat oleh mahasiswa sangat dangkal serta konten materi yang disajikan persis seperti refrensi yang digunakan oleh mahasiswa dalam membuat materi tersebut. Untuk memperbaiki dan meningkatkan kualitas pembelajaran dan hasil belajar mahasiswa, maka diperlukan penyerasian proses pembelajaran yang didukung perangkat yang baik dengan pengembangan perangkat pembelajaran. Inovasi pembelajaran perlu dilakukan dalam upaya mengatasi kelemahan yang dihadapi dalam proses pembelajaran. Salah satu inovasi pembelajaran yang bisa dilakukan adalah mengintegrasikan strategi pembelajaran think talk write (TTW) dalam perangkat pembelajaran. 
Strategi pembelajaran TTW pada dasarnya merupakan strategi pembelajaran yang dibentuk dengan proses berpikir, berdialog serta menulis. Alur strategi TTW diawali dari keterlibatan siswa dalam berpikir ataupun memproses data dalam dirinya sendiri melalui proses membaca. Berikutnya proses berdialog dengan cara sharing dengan teman dalam kelompoknya selanjutnya adalah proses menulis (Caitra, 2019; Kusuma, 2020; Monica, 2020).

Tahapan berpikir (think) bisa dilihat dari proses membaca sesuatu bacaan setelah itu membuat catatan apa yang sudah dibaca. Dalam menulis catatan siswa diharapkan mampu menyatukan data, informasi yang didapat dalam bacaan selanjutnya akan disimpulkan dalam bentuk tulisan dengan Bahasa sendiri. Menurut Wiederhold (1997 dalam Ansari, 2008:85) menyatakan bahwa membuat catatan berarti menganalisis tujuan isi bacaan sekalian mengecek bahan-bahan yang ditulis. Tidak hanya itu aktivitas menulis akan mampu meningkatkan pengetahuan siswa, serta kegiatan ini akan mampu meningkatkan kemampuan berpikir dan menulis siswa.

Tahap think akan dapat meningkatkan kemampuan kognitif yang dimiliki oleh siswa. Pada tahap ini siswa diberikan kesempatan untuk mengelaborasi keterampilan berpikir masing-masing siswa. Siswa akan menjadi terlatih untuk menggunakan keterampilan berpikir untuk memecahkan permasalahan yang dihadapi. Dengan meningkatnya kemampuan kognitif siswa akan dapat meningkatkan pemahaman siswa serta kemampuan berpikir kritis.

Kegiatan pada tahap think akan mampu meningkatkan kompetensi siswa khususnya pada ranah kognitif yang dimiliki oleh siswa. Tahapan ini akan memberikan peluang bagi siswa untuk mengelaborasi keahlian siswa dalam berpikir. Melalui kegiatan think akan membuat siswa terlatih dalam berpikir, memecahkan permasalahan yang dihadapi sehingga nantinya mampu meningkatkan kemampuan siswa untuk berpikir kritis.

Tahap selanjutnya adalah talk, pada tahapan ini siswa diajak untuk berbicara dengan memakai kata-kata sendiri. Tahapan ini sangat penting karena: (1) data yang diperoleh berupa tulisan, foto, isjarat, ataupun obrolan merupakan ungkapan dari Bahasa, (2) melalui interaksi antar sesame teman akan mampu menciftakan sesuatu yang bermakna, (3) melalui proses berbicara akan mampu mengungkapkan ide/gagasan dengan menggunakan kata-kata sendiri, (4) pembentukan ide (forming ideas), artinya dalam proses ini tidak jarang akan melahirkan ide atau gagasan baru yang terus dapat dikembangkan atau pun direvisi, (5) internalisasi ide, (6) meningkatkan dan menilai kualitas berpikir.

Selanjutnya adalah tahap write, yaitu menuliskan hasil diskusi atau dialog pada lembar kerja yang disediakan. Aktivitas menulis adalah proses mengkonstruksi ide, karena setelah berdiskusi/berdialog antar teman akan melahirkan ide-ide yang nantinya dapat dituangkan dalam bentuk tulisan. Menulis hasil diskusi dalam pembelajaran sains telah mampu merealisasikan tujuan dari pembelajaran yaitu, meningkatkan hasil belajar dan kemampuan berpikir utamanya adalah berpikir kritis.

Berikutnya adalah tahapan write, ialah menuliskan hasil dialog ataupun diskusi pada lembar kerja yang disediakan. Kegiatan menulis merupakan proses mengkonstruksi gagasan, karena hasil dari diskusi antar kelompok akan mampu melahirkan ide-ide yang nantinya bisa dituangkan dalam tulisan. Melalui kegiatan menulis akan mampu meningkatkan hasil belajar serta kemampuan dalam berpikir siswa.

Berdasarkan permasalahan yang telah diuraikan di atas maka dalam penelitian ini akan dilakukan pengintegrasikan penanaman nilai karakter tri kaya parisudha dengan strategi pembelajaran think talk write melalui pengembangan buku ajar evaluasi pembelajaran anak usia dini. Berdasarkan uraian tersebut di atas, penelitian ini bertujuan menghasilkan perangkat pembelajaran evaluasi pembelajaran anak usia dini bermuatan 
karakter tri kaya parisudha dengan strategi think talk write yang valid dan praktis sehingga nantinya layak digunakan untuk buku ajar pada Program Studi PG PAUD, Sekolah Tinggi Agama Hindu Negeri Mpu Kuturan Singaraja.

\section{Metode Penelitian}

Penelitian ini adalah penelitian eksperimen dengan model Research and Development $(R \& D)$ atau penelitian dan pengembangan. Model penelitian ini mengacu pada model pengembangan dari Borg and Gall. Terdapat sepuluh langkah-langkah Borg and Gall (Sugiyono, 2017). Adapun skema atau gambaran tahapan pengembangan produk dari Borg and Gall adalah sebagai berikut:

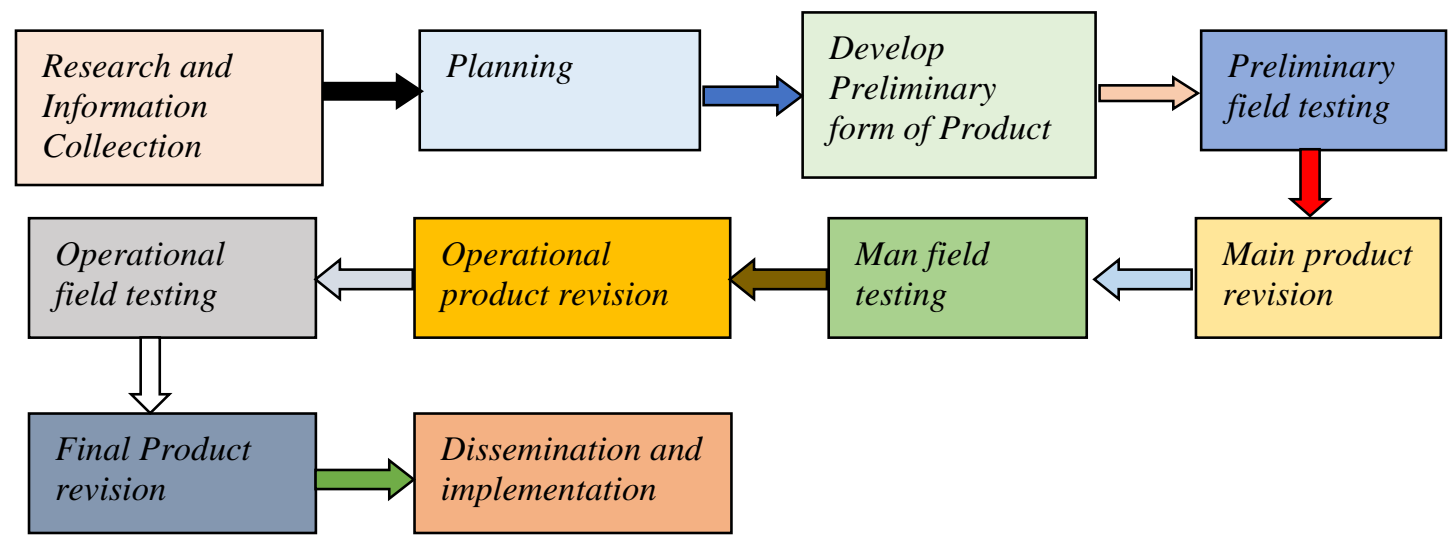

Gambar 1. Model Pengembangan Borg and Hall (Sugiyono, 2017)

Prosedur pengembangan dalam penelitian ini adalah sebagai berikut:

Tabel 1. Prosedur Pengembangan Buku Ajar

\begin{tabular}{|l|l|l|}
\hline No & Langkah Pengembangan & \multicolumn{1}{c|}{ Kegiatan } \\
\hline 1 & $\begin{array}{l}\text { Research And Information } \\
\text { Collecting (Penelitian dan } \\
\text { pengumpulan data) }\end{array}$ & $\begin{array}{l}\text { survey dan observasi digunakan untuk menganalisis } \\
\text { kebutuhan, mengindentifikasi serta mengumpulkan } \\
\text { informasi sehingga perlunya pengembangan produk } \\
\text { baru. }\end{array}$ \\
\hline 2 & Planning (Perencanaan) & $\begin{array}{l}\text { Melakukan perencanaan, artinya pada tahap ini } \\
\text { adalah merencanakan desain produk yang } \\
\text { dikembangkan untuk memecahkan masalah. } \\
\text { Perencanaan pada penelitian ini adalah merancang } \\
\text { buku ajar bermuatan karakter tri kaya parisudha } \\
\text { dengan strategi think talk write. }\end{array}$ \\
\hline 3 & $\begin{array}{l}\text { Develop Preliminary Form } \\
\text { Of Product (Pengembangan } \\
\text { draf produk). }\end{array}$ & $\begin{array}{l}\text { Pada tahap ini adalah mengembangkan produk awal, } \\
\text { meliputi pengembangan draft rancangan materi } \\
\text { yang dikembangkan, draft awal buku ajar, } \\
\text { instrument validasi buku ajar. Pada tahap ini akan } \\
\text { dilakukan validasi terkait dengan draft buku ajar } \\
\text { yang dibuat dengan melibatkan ahli di bidang } \\
\text { pendidikan pendidikan anak usia dini, media } \\
\text { pembelajaran serta pakar Bahasa Indonesia. Hasil } \\
\text { yang didapatkan dari proses validasi serta masukan } \\
\text { dari validator akan dijadikan acuan dalam } \\
\text { melakukan revisi draft buku ajar. }\end{array}$ \\
\hline
\end{tabular}




\begin{tabular}{|c|c|c|}
\hline 4 & $\begin{array}{l}\text { Preliminary Field Testing } \\
\text { (Uji coba lapangan awal ) }\end{array}$ & $\begin{array}{l}\text { Tahap berikutnya merupakan tahap uji coba } \\
\text { terbatas. } \\
\text { Hasil uji coba terbatas selanjutnya dianalisis dan } \\
\text { dievaluasi untuk dilakukan perbaikan terhadap buku } \\
\text { ajar yang telah dikembangkan. Pengujian pada } \\
\text { penelitian ini dilakukan pada beberapa orang } \\
\text { mahasiswa Prodi PG PAUD Semester VI, untuk } \\
\text { memastikan kegiatan buku ajar sesuai dengan } \\
\text { tuntutan kurikulum }\end{array}$ \\
\hline 5 & $\begin{array}{l}\text { Main Product Revision } \\
\text { (Merevisi hasil uji coba) }\end{array}$ & $\begin{array}{l}\text { Pada tahapan ini akan dilakukan revisi utama } \\
\text { terhadap produk didasarkan pada saran-saran uji } \\
\text { coba pada kelompok terbatas. Bila ada kendala } \\
\text { dalam proses pelaksanaannya, dilakukan revisi } \\
\text { kegiatan. }\end{array}$ \\
\hline 6 & $\begin{array}{l}\text { Main Field Testing (Uji } \\
\text { coba lapangan) }\end{array}$ & $\begin{array}{l}\text { Setelah revisi, diuji coba dilanjutkan pada kelompok } \\
\text { yang lebih besar. Uji coba ini dilakukan untuk } \\
\text { mengimplementasikan buku ajar yang } \\
\text { dikembangkan pada kelompok yang lebih luas serta } \\
\text { pada kondisi yang real sesuai dengan materi buku } \\
\text { ajar yang dikembangkan. Uji coba pada kelompok } \\
\text { yang lebih besar dilakukan pada semester V pada } \\
\text { prodi Pendidikan Guru Anak Usia Dini, STAHN } \\
\text { Mpu Kuturan Singaraja. }\end{array}$ \\
\hline 7 & $\begin{array}{l}\text { Operasional Product } \\
\text { Revision (Penyempurnaan } \\
\text { produk hasil uji lapangan). }\end{array}$ & $\begin{array}{l}\text { Setelah dilakukan uji coba pada kelompok yang } \\
\text { lebih luas selanjutnya akan di evaluasi serta } \\
\text { diperbaiki sesuai saran-saran yang diperoleh dari } \\
\text { saran yang didapatkan selama proses uji coba demi } \\
\text { penyempurnaan draft buku ajar yang dibuat. }\end{array}$ \\
\hline
\end{tabular}

Berdasarkan waktu penelitian, pengembangan yang dilakukan pada penelitian ini hanya sampai pada langkah ke-tujuh, langkah ke-delapan sampai ke-sepuluh ditiadakan. Namun pelaksanaan langkah selanjutnya dapat dilakukan pada jadwal di luar penelitian.

Pengumpulan data penelitian dilakukan dengan menggunakan instrumen yang telah dirancang kemudian dianalisis untuk mengevaluasi validitas dan kepraktisan buku ajar.

\section{Validitas Buku Ajar}

Validitas buku ajar dalam penelitian ini terdiri dari validitas isi dan validitas konstruk. Pengumpulan data terkait dengan validitas isi menggunakan lembar validasi pendapat validator menggunakan skala 5 dengan kategori; skor $5=$ sangat baik, skor $4=$ baik, skor $3=$ cukup, skor $2=$ kurang, dan skor $1=$ sangat kurang. Untuk melihat validitas buku ajar ditentukan dengan mengkonversikan rata-rata skor total menjadi nilai kualitatif dengan menggunakan kriteria berikut.

Tabel 2. Kriteria Nilai Rata-rata Skala Lima

\begin{tabular}{|c|c|l|}
\hline Nilai & Interval skor & \multicolumn{1}{c|}{ Kategori } \\
\hline 5 & $>4,20$ & Sangat baik \\
\hline 4 & $3,41-4,20$ & Baik \\
\hline 3 & $2,61-3,40$ & Cukup \\
\hline
\end{tabular}




\begin{tabular}{|c|c|l|}
\hline 2 & $1,81-2,60$ & Kurang \\
\hline 1 & $\leq 1,80$ & Sangat kurang \\
\hline
\end{tabular}

(Widoyoko, 2009)

Dalam penelitian ini ditetapkan kelayakan produk minimal mencapai kategori baik sehingga produk layak digunakan dalam pembelajaran di kelas.

\section{Kepraktisan Buku Ajar}

Kepraktisan buku ajar yang dikembangkan dianalisis dari penggunaan buku ajar tersebut pada pembelajaran di kelas. Data kepraktisan buku ajar didapatkan dari hasil observasi serta respon mahasiswa terhadap buku ajar yang digunakan. Data yang diperoleh kemudian dianalisis untuk mendapatkan nilai kepraktisannya. Rata-rata skor dari pengamat dan respon mahasiswa dikonversi ke dalam Tabel 4.

Tabel 3. Kriteria Kepraktisan Bahan Ajar

\begin{tabular}{|c|c|}
\hline Skor & Kategori \\
\hline $3,5 \leq \mathrm{Sr}<4,0$ & Sangat praktis \\
\hline $2,5 \leq \mathrm{Sr}<3,5$ & Praktis \\
\hline $1,5 \leq \mathrm{Sr}<2,5$ & Tidak praktis \\
\hline $1,0 \leq \mathrm{Sr}<1,5$ & Sangat tidak praktis \\
\hline
\end{tabular}

(Sadra, 2007)

Keterangan:

$\mathrm{Sr} \quad=$ skor rata-rata

$\mathrm{Sr} \quad=\frac{\text { jumlah } \text { skor semua item }}{\text { banyak item }}$

Indikator kepraktisan buku ajar pada penelitian ini berada pada interval $2,5 \leq \mathrm{Sr}$ $<3.5$, dengan ketagori praktis.

\section{Hasil Dan Pembahasan}

\section{Planning (Perencanaan)}

Tahapan perencanaan diawali dengan melakukan analisis kebutuhan pengembangan buku ajar bermuatan karakter Tri Kaya Parisudha dengan setting think talk write, analisis capaian mata kuliah (CP) khususnya pada mata kuliah evaluasi perkembangan anak usia dini, serta penetapan kompetensi, indicator pencapaian serta materi pokok yang akan dikembangkan dalam pembuatan buku ajar bermuatan karakter Tri Kaya Parisudha dengan setting think talk write. Adapun materi yang dipilih untuk dirancang sebagai buku ajar evaluasi penialaian anak usia dini bermuatan pendidikan karakter dengan strategi think talk write adalah sebagai berikut.

Tabel 4. Pemetaan Materi Buku Ajar Evaluasi Anak Usia Dini

\begin{tabular}{|c|c|c|}
\hline Kompetensi Dasar & Indikator Pencapaian & Materi Pokok \\
\hline $\begin{array}{l}\text { Memahami hakekat } \\
\text { evaluasi pembelajaran }\end{array}$ & $\begin{array}{l}\text { 1. Menjelaskan tentang pengertian } \\
\text { asesmen pembelajaran } \\
\text { 2. Menjelaskan perbedaan asesmen, } \\
\text { pengukuran, tes dan evaluasi } \\
\text { 3. Menjelaskan tentang perbedaan } \\
\text { asesmen dan evaluasi } \\
\text { 4. Menjelaskan hubungan antara } \\
\text { asesmen, pengukuran, tes dan } \\
\text { evaluasi }\end{array}$ & $\begin{array}{l}\text { Hakekat } \\
\text { asesmen } \\
\text { pembelajaran }\end{array}$ \\
\hline
\end{tabular}




\begin{tabular}{|c|c|c|}
\hline $\begin{array}{l}\text { Memahami evaluasi } \\
\text { perkembangan untuk anak } \\
\text { usia dini }\end{array}$ & $\begin{array}{l}\text { 1. Menjelaskan tentang pengertian } \\
\text { anak usia dini } \\
\text { 2. Menjelaskan aspek-aspek } \\
\text { perkembangan anak usia dini } \\
\text { 3. Menjelaskan prinsip-prinsip } \\
\text { asesmen anak usia dini } \\
\text { 4. Menjelaskan tentang lingkup } \\
\text { asesmen anak usia dini } \\
\text { 5. Menjelaskan tentang tujuan } \\
\text { asesmen anak usia dini } \\
\text { 6. } \begin{array}{l}\text { Menjelaskan tentang manfaat } \\
\text { asesmen anak usia dini }\end{array}\end{array}$ & $\begin{array}{l}\text { Evaluasi } \\
\text { perkembangan } \\
\text { anak usia dini }\end{array}$ \\
\hline $\begin{array}{l}\text { Memahami cara } \\
\text { mengevaluasi } \\
\text { perkembangan } \\
\text { fisik/motorik pada anak } \\
\text { usia dini }\end{array}$ & $\begin{array}{l}\text { 1. Menjelaskan tahap perkembangan } \\
\text { fisik/motorik pada anak usia dini } \\
\text { 2. Menjelaskan indikator pencapaian } \\
\text { tahap perkembangan fisik/motorik } \\
\text { pada anak usia dini } \\
\text { 3. Menjelaskan cara menyusun } \\
\text { instrumen untuk asesmen } \\
\text { perkembangan fisik/motorik pada } \\
\text { anak usia dini } \\
\text { 4. Menjelaskan teknik pengumpulan } \\
\text { data perkembangan fisik/motorik } \\
\text { pada anak usia dini } \\
\text { Menjelaskan cara menganalisis data } \\
\text { perkembangan fisik/motorik pada } \\
\text { anak usia dini } \\
\text { Memberikan contoh asesmen } \\
\text { perkembangan fisik/motorik pada } \\
\text { anak usia dini. }\end{array}$ & $\begin{array}{l}\text { Evaluasi } \\
\text { Perkembangan } \\
\text { fisik/motorik } \\
\text { anak usia dini }\end{array}$ \\
\hline $\begin{array}{l}\text { Memahami cara evaluasi } \\
\text { perkembangan kognitif } \\
\text { pada anak usia dini }\end{array}$ & $\begin{array}{l}\text { 1. Menjelaskan tahap perkembangan } \\
\text { kognitif anak usia dini } \\
\text { 2. Menjelaskan indikator pencapaian } \\
\text { tahap perkembangan kognitif } \\
\text { 3. Menjelaskan cara menyusun } \\
\text { instrumen untuk asesmen } \\
\text { perkembangan kognitif } \\
\text { 4. Menjelaskan teknik pengumpulan } \\
\text { data perkembangan kognitif } \\
\text { 5. Menjelaskan cara menganalisis data } \\
\text { perkembangan kognitif } \\
\text { 6. Memberikan contoh asesmen } \\
\text { perkembangan kognitif }\end{array}$ & $\begin{array}{l}\text { Evaluasi } \\
\text { Perkembangan } \\
\text { kognitif anak } \\
\text { usia dini }\end{array}$ \\
\hline $\begin{array}{l}\text { Memahami cara evaluasi } \\
\text { perkembangan bahasa } \\
\text { anak usia dini }\end{array}$ & $\begin{array}{l}\text { 1. Menjelaskan tahapan } \\
\text { perkembangan bahasa anak usia } \\
\text { dini } \\
\text { 2. Menjelaskan tentang indikator } \\
\text { pencapaian perkembangan bahasa } \\
\text { anak usia dini }\end{array}$ & $\begin{array}{l}\text { Evaluasi } \\
\text { Perkembangan } \\
\text { bahasa anak } \\
\text { usia dini }\end{array}$ \\
\hline
\end{tabular}




\begin{tabular}{|c|c|c|}
\hline & $\begin{array}{l}\text { 3. Menjelaskan tentang penyusunan } \\
\text { instrumen perkembangan bahasa } \\
\text { anak usia dini } \\
\text { 4. Menjelaskan tentang analisis data } \\
\text { perkembangan anak usia dini } \\
\text { 5. Membuat contoh asesmen } \\
\text { perkembangan bahasa anak usia } \\
\text { dini. }\end{array}$ & \\
\hline $\begin{array}{l}\text { Memahami cara evaluasi } \\
\text { perkembangan sosial } \\
\text { emosional pada anak usia } \\
\text { dini }\end{array}$ & $\begin{array}{l}\text { 1. Menjelaskan tahap perkembangan } \\
\text { sosioemosional anak usia dini } \\
\text { 2. Menjelaskan indikator pencapaian } \\
\text { perkembangan sosioemosional anak } \\
\text { usia dini } \\
\text { 3. Menjelaskan cara menyususn } \\
\text { instrumen untuk asesmen } \\
\text { perkembangan sosioemosional anak } \\
\text { usia dini } \\
\text { 4. Menjelaskan cara menganalisis data } \\
\text { perkembangan sosioemosional anak } \\
\text { usia dini } \\
\text { 5. Memberikan contoh asesmen } \\
\text { perkembangan sosioemosional anak } \\
\text { usia dini. }\end{array}$ & $\begin{array}{l}\text { Evaluasi } \\
\text { Perkembangan } \\
\text { sosioemosional } \\
\text { anak usia dini }\end{array}$ \\
\hline $\begin{array}{l}\text { Memahami cara membuat } \\
\text { laporan perkembangan } \\
\text { anak usia dini }\end{array}$ & $\begin{array}{l}\text { 1. Menjelaskan pengertian pelaporan } \\
\text { perkembangan anak usia dini } \\
\text { 2. Menjelaskan tujuan pelaporan } \\
\text { perkembangan anak usia dini } \\
\text { 3. Menjelaskan ruang lingkup } \\
\text { pelaporan perkembangan anak usia } \\
\text { dini } \\
\text { 4. Menjelaskan manfaat pelaporan } \\
\text { perkembangan anak usia dini } \\
\text { 5. Menjelaskan teknik penyusunan } \\
\text { pelaporan perkembangan anak usia } \\
\text { dini } \\
\text { 6. Memberikan contoh pelaporan } \\
\text { perkembangan berdasarkan } \\
\text { pengumpulan data. }\end{array}$ & $\begin{array}{l}\text { Pelaporan } \\
\text { perkembangan } \\
\text { anak usia dini } \\
\text { Hakikat } \\
\text { pelaporan } \\
\text { perkembangan } \\
\text { anak usia dini }\end{array}$ \\
\hline
\end{tabular}

\section{Develop Preliminary Form Of Product (Pengembangan draf produk)}

Pengembangan draf produk awal yang dilakukan adalah menyiapkan materi untuk buku ajar yang akan dikembangkan, menyusun instrument validasi terkait dengan draf buku ajar yang dikembangkan. Proses penelitian dilakukan dengan validasi rancangan produk oleh pakar ahli dibidangnya. Penilaian dilakukan oleh ahli isi, ahli media serta ahli Bahasa. Hasil dari validasi dari para ahli akan digunakan untuk memperbaiki draf buku ajar. Berdasarkan hasil analisis dari bahasa dan validasi isi dapat dilihat pada Tabel 5 dan Tabel 6. 
Tabel 5. Saran Hasil Validasi Bahasa Terhadap Buku

\begin{tabular}{|l|l|}
\hline No & \multicolumn{1}{c|}{ Saran } \\
\hline 1 & Penulisan cover pada buku siswa disesuaikan dengan EYD \\
\hline 2 & Konsitensi penggunaan symbol dalam buku siswa. \\
\hline 3 & Penulisan untuk petunjuk kegiatan sesuaikan dengan EYD \\
\hline 4 & $\begin{array}{l}\text { Perbaikan deskripsi masalah pada kegiatan unit IV, belum sesuai dengan } \\
\text { tujuan kegiatan }\end{array}$ \\
\hline 5 & Kesalahan beberapa tata tulis perlu dilakukan cek lebih hati-hati. \\
\hline
\end{tabular}

Tabel 6. Ringkasan Hasil Validasi Buku Ajar

\begin{tabular}{|l|l|c|c|}
\hline No & \multicolumn{1}{|c|}{ Aspek Validasi } & Rata-Rata & Kategori \\
\hline 1 & Isi buku ajar & 4.42 & Sangat baik \\
\hline 2 & $\begin{array}{l}\text { Cara penyajian buku } \\
\text { secara umum }\end{array}$ & 4.40 & Sangat baik \\
\hline 3 & $\begin{array}{l}\text { Bentuk fisik buku } \\
\text { secara umum }\end{array}$ & 4.75 & Sangat baik \\
\hline & Rata-rata & $\mathbf{4 . 5 2}$ & Sangat baik \\
\hline
\end{tabular}

\section{Preliminary Field Testing (Uji coba lapangan awal)}

Tahap berikutnya adalah uji pada kelompok kecil (uji coba terbatas). Data yang diperoleh dari uji ini, selanjutnya dianalisis dan dievaluasi. Hasil analisis dan evalusi pada tahap ini akan digunakan sebagai dasar memperbaiki produk pada penerapan berikutnya. Pengujian pada penelitian ini dilakukan pada beberapa orang mahasiswa Prodi PG PAUD Semester 6, untuk memastikan buku ajar sesuai dengan tuntutan kurikulum. Secara umum dalam uji coba terbatas tidak terdapat masukan yang signifikan sehingga draf buku layak digunakan dalam proses pembelajaran di kelas.

\section{Main Product Revision (Merevisi hasil uji coba)}

Langkah selanjutnya adalah melakukan revisi terhadap draf buku yang dikembangkan. Berdasarkan hasil analisis pada uji coba lapangan awal, secara umum tidak ditemukan kendala dalam proses pembelajaran. Dengan kata lain draf buku ajar ini sudah menjadi draf final yang dapat digunakan dalam proses pembelajaran di kelas sesungguhnya.

\section{Main Field Testing (Uji coba lapangan)}

Proses dari tahap ini adalah untuk implementasi produk sebagai produk yang dikembangkan dalam wilayah yang lebih luas dan kondisi yang lebih nyata. Kegiatan ini akan dilakukan pada semester IV Kelas Prodi PG PAUD, STAHN Mpu Kuturan Singaraja. Pengujian ini bertujuan untuk mengetahui kepraktisan bahan ajar yang dikembangkan. Selama proses pembalajaran tidak ditemukan kendala yang berarti dalam penggunaan buku ajar evaluasi pembelajaran anak usia dini bermuatan pendidikan karakter dengan strategi think talk write. Data kepraktisan buku ajar diukur dengan membagikan kuisioner diakhir proses pembelajaran. Adapun data hasil pengukuran dapat dilihat pada Tabel 7. 
Tabel 7. Ringkasan Respon Mahasiswa Terhadap Buku Ajar

\begin{tabular}{|c|c|c|}
\hline \multirow[b]{2}{*}{ Aspek yang ditanyakan } & \multicolumn{2}{|c|}{ Hasil Penilaian } \\
\hline & $\begin{array}{l}\text { Rata-rata } \\
\text { skor }\end{array}$ & Kriteria \\
\hline 1. Saya senang mempelajari buku ini & 3.61 & Baik \\
\hline 2. Saya melihat tampilan dari buku ini menarik & 3.67 & Baik \\
\hline $\begin{array}{l}\text { 3. Materi yang ada di dalam buku ini menarik } \\
\text { untuk dibaca }\end{array}$ & 3.94 & Baik \\
\hline $\begin{array}{l}\text { 4. Saya merasa tertantang untuk menemukan } \\
\text { masalah tentang materi }\end{array}$ & 3.94 & Baik \\
\hline $\begin{array}{l}\text { 5. Buku ini membantu saya untuk menemukan } \\
\text { jawaban sementara dari masalah yang saya } \\
\text { temukan }\end{array}$ & 4.03 & Baik \\
\hline $\begin{array}{l}\text { 6. Materi dalam buku ini disajikan terurut, rapi } \\
\text { sehingga memudahkan untuk dipahami }\end{array}$ & 3.56 & Baik \\
\hline $\begin{array}{l}\text { 7. Melalui buku ajar ini, saya menjadi lebih } \\
\text { mudah memahami materi yang diberikan }\end{array}$ & 3.92 & Baik \\
\hline $\begin{array}{l}\text { 8. Melalui buku ajar ini, saya mendapatkan } \\
\text { pemahaman yang medalam dari materi yang } \\
\text { dipelajari }\end{array}$ & 3.89 & Baik \\
\hline $\begin{array}{l}\text { 9. Memalui buku ajar ini, saya mendapatkan } \\
\text { pengetahuan luas tentang materi yang saya } \\
\text { pelajari }\end{array}$ & 3.42 & Baik \\
\hline $\begin{array}{l}\text { 10. Tugas yang harus saya kerjakan dalam buku } \\
\text { ini jelas }\end{array}$ & 3.86 & Baik \\
\hline $\begin{array}{l}\text { 11. Tugas-tugas pada buku ini tidak membebani } \\
\text { saya }\end{array}$ & 3.75 & Baik \\
\hline $\begin{array}{l}\text { 12. Buku ini dapat membantu saya dalam } \\
\text { berinteraksi dengan guru maupun siswa yang } \\
\text { lain }\end{array}$ & 3.75 & Baik \\
\hline $\begin{array}{l}\text { 13. Melalui buku ini, saya dapat menyelesaikan } \\
\text { masalah yang diberikan baik secara individu } \\
\text { maupun kelompok }\end{array}$ & 3.56 & Baik \\
\hline $\begin{array}{l}\text { 14. Buku ini dapat memberikan saya kenyamanan } \\
\text { dalam belajar }\end{array}$ & 3.72 & baik \\
\hline $\begin{array}{l}\text { 15. Karakter yang ingin dilatihkan dalam buku ini } \\
\text { mudah saya pahami }\end{array}$ & 3.92 & Baik \\
\hline $\begin{array}{l}\text { 16. Kalimat yang digunakan dalam buku ini } \\
\text { mudah dipahami }\end{array}$ & 3.83 & Baik \\
\hline $\begin{array}{l}\text { 17. Gambar maupun tabel yang digunakan pada } \\
\text { buku ini jelas }\end{array}$ & 3.81 & Baik \\
\hline $\begin{array}{l}\text { 18. Dengan adanya buku ini, saya menjadi lebih } \\
\text { mengetahui akan manfaat dari materi yang } \\
\text { telah dipelajari serta karakter apa yang perlu } \\
\text { dilatihkan setiap kita belajar }\end{array}$ & 3.56 & Baik \\
\hline $\begin{array}{l}\text { 19. Saya ingin selalu mempraktekkan nilai-nilai } \\
\text { karakter yang ada di dalam buku ini. }\end{array}$ & 3.69 & Baik \\
\hline Rata-rata total & 3.76 & Baik \\
\hline
\end{tabular}


Berdasarkan tabel di atas terlihat bahwa rata-rata skor yang diperoleh dari respon gsiswa terhadap bahan ajar yang dikembangkan adalah 3,76 dari skor maksimum 5,00.

Berdasarkan hasil analisis data penelitian menunjukkan bahwa buku ajar yang dikembangkan telah memenuhi kualitas yang baik dari segi validitas dan kepraktisan. Berikut ini dipaparkan lebih lanjut tentang validitas bahan ajar dan tingkat kepraktisan pembelajaran.

\section{Validitas Buku Ajar Evaluasi Pembelajaran Anak Usia Dini Bermuatan Karakter Dengan Setting Think Talk Write}

Validasi buku ajar ditempuh melalui validasi isi dari para pakar dan validasi empiris. Hasil penilaian validasi isi terhadap buku ajar didapatkan rata-rata 4,55 atau berada dalam kategori sangat baik. Hasil pengembangan bahan ajar dalam penelitian ini berada dalam kategori sangat baik, disebabkan oleh beberapa faktor antara lain sebagai berikut.

a. Buku ajar evalausi pembelajaran anak usia dini bermuatan karakter Tri Kaya Parisudha dengan setting think talk write yang dikembangkan sesuai dengan tuntutan kurikulum KKNI, yaitu pengembangan bahan ajar berorientasi pada pendekatan saintifik. Dimana dalam penelitian ini buku ajar yang dikembangkan dengan strategi think talk write. Selain itu, pemilihan topik, kedalaman materi dan langkah-langkah pembelajaran yang disusun telah mengacu pada capaian pembelajaran yang ada pada kurikulum KKNI.

b. Buku ajar yang dikembangkan telah memenuhi indikator validitas, dalam pengembangan buku ajar ini didapatkan validitas isi dan validitas konstruk dalam kategori valid. Validitas isi yang dimaksud dalam pengembangan ini didasarkan pada kesesuaian materi buku ajar dengan teori yang dijadikan acuan dalam pengembangan buku ini, kesesuaian dengan karakter tri kaya parisudha dan kesesuaian langkah pembelajaran dengan strategi think talk write. Validitas konstruk dalam buku ajar ini memperhatikan keterkaitan komponen buku ajar tersusun secara sistematis. Dengan adanya kegiatan mahasiswa pada buku ajar memungkinkan mahasiswa mengkonstruksi sendiri pengetahuannya sesuai dengan sub materi yang diberikan sehingga mahasiswa mampu mengkonstuksi pengetahuannya sendiri.

c. Komponen-komponen buku ajar yang dikembangkan sesuai dengan indikator yang telah ditetapkan pada instrumen validasi. Hal ini berarti penyajian buku ajar secara umum baik dari segi tampilan, isi materi, dan penggunaan bahasa telah memenuhi dan sesuai dengan indikator yang menjadi acuan dalam menilai kualitas bahan ajar.

Berdasarkan alasan tersebut, buku ajar evaluasi pembelajaran anak usia dini bermuatan karakter tri kaya parisudha dengan setting think talk write memenuhi kriteria valid sesuai dengan yang diharapkan, baik dari segi isi maupun konstruknya, sehingga layak untuk digunakan dalam pembelajaran.

\section{Tingkat Kepraktisan Ajar Evaluasi Pembelajaran Anak Usia Dini Bermuatan Karakter Dengan Setting Think Talk Write}

Kepraktisan bahan ajar dapat diketahui dari respon mahasiswa terhadap buku ajar. Kepraktisan ini mencerminkan kemudahan siswa dalam penggunaan buku ajar yang sesuai dengan alokasi waktu yang sudah didetetapkan, begitu pula dengan penggunaan alat, bahan, dan media yang digunakan dalam pembelajaran mudah didapatkan sehingga respon positif diberikan oleh mahasiswa terhadap penggunaan buku ajar dalam pembelajaran. Berdasarkan hasil data observasi penggunaan waktu serta skor rata-rata respon mahasiswa menunjukkan bahwa buku ajar yang dikembangkan termasuk dalam kategori praktis. Sementara itu, kepraktisan bahan ajar juga dilihat dari respon mahasiswa terhadap buku 
ajar, dari hasil penelitian didapatkan nilai respon siswa sebesar 3.72 yang berarti buku siswa praktis/baik digunakan oleh siswa.

Secara umum, pengembangan buku ajar ini telah memenuhi syarat kepraktisan yaitu berada dalam kategori baik/praktis. Berdasarkan hasil refleksi dari uji coba yang telah dilakukan, maka ada beberapa hal positif yang terjadi selama pembelajaran, yaitu:

a. Buku ajar membantu dosen dalam pembelajaran karena dalam buku ini berisi langkahlangkah pembelajaran yang harus dilaksanakan dalam proses pembelajaran di kelas.

b. Mahasiswa mulai terbiasa melakukan kegiatan (tugas) serta membuat laporan secara ilmiah sehingga nantinya akan memudahkan mahasiswa untuk membuat laporan ilmiah pada kegiatan dan topik pelajaran lain.

c. Menumbuhkan sikap karekater berbasis nilai tri kaya parisudha kerjasama dan tanggung jawab melalui kerja kelompok yang dirancang dalam proses pembelajaran.

d. Memberikan pengalaman kepada mahasiswa tentang perubahan paradigma belajar dari teacher centered menjadi student centered.

Berdasarkan uraian di atas dapat disimpulkan bahwa pengembangan buku ajar evaluasi pembelajaran anak usia dini bermuatan nilai karakter tri kaya parisudha dengan setting thik talk write yang dikembangkan telah memenuhi syarat kepraktisan buku ajar, sehingga layak digunakan oleh mahasiswa sebagai buku pegangan.

\section{Kesimpulan}

Dari hasil analisis data penelitian, simpulan penelitian ini adalah sebagai berikut: (1) buku ajar evaluasi pembelajaran anak usia dini bermuatan nilai karakter tri kaya parisudha dengan setting thik talk write telah memenuhi kelayakan validitas isi dengan skor 4,52 berada pada kategori sangat baik, (2) buku ajar evaluasi pembelajaran anak usia dini bermuatan nilai karakter tri kaya parisudha dengan setting thik talk write telah memenuhi kepraktisan dilihat dari aspek penggunaan waktu yang tergolong efesien, serta skor siswa yang yaitu sebesar 3,72 berada pada kategori baik.

\section{Daftar Pustaka}

Adnyana, P. B dan Citrawathi, D. M. (2017). Model Pendidikan Karater Berbasis Tri Kaya Parisudha Terintegrasi Dalam Pembelajaran di Sekolah Dasar. SEMINAR NASIONAL RISET INOVATIF 2017 ISBN: 978-602-6428-11-0.

Caitra, Z. D. (2019). Pengembangan Perangkat Pembelajaran Model Think Talk Write Subtema Hidup Rukun Untuk Meningkatkan Kemampuan Berpikir Kritis Siswa Kelas V Sekolah Dasar. Jurnal Review Pendidikan Dasar: Jurnal Kajian Pendidikan Dan Hasil Penelitian, 5(2), 949. https://doi.org/10.26740/jrpd.v5n2.p949-957.

Kusuma, Mujib, Syahputra, A. (2020). Perangkat, Pengembangan Kooperatif, Pembelajaran Think, Tipe Write, Talk Meningkatkan, Untuk Siswa, Representasi Matematis Kusuma, Nita Mujib, Abdul Syahputra, Edi Ariswoyo, Suwarno Kooperatif, Pembelajaran Think, Tipe Write, Talk Matematis, Representasi. EDUMASPUL: Jurnal Pendidikan, 4(2), 39-45.

Lichona, T. 1991. Educating for Character (Mendidik untuk Membentuk Karakter): Bagaimana Sekolah Dapat Memberikan Pendidikan tentang Sikap Hormat dan Tanggung Jawab. Terjemahan Juma Abdu Wamaungo, 2012. Jakarta: Bumi Aksara.

Lodra, I W. 2006. Trikaya Parisudha dalam Segala Aspek Kehidupan. WHD, 465: 26 29. 
Monica, T, N. (2020). Pengembangan Bahan Ajar Keterampilan Menulis Narasi Menggunakan Strategi Think, Talk, Write (TTW). Jurnal Education and Development, 8(4), 448-454.

Parmajaya, I. P. G. (2018). Mengenal Taksonomi Nilai Berbasis Tri Kaya Parisudha Sebagai Alat Ukur Psikologis Dalam Proses Pembelajaran. Singaraja: STAHN Mpu Kuturan Singaraja.

Puja. (1981). Sarasamuscaya. Jakarta: Departemen Agama.

Sadra,I W. 2007. Pengembangan Pembelajaran Matematikan Berwawasan Lingkungan dalam Pelatihan Guru Kelas I SD. makalah disampaikan dalam seminar.

Sugiyono. (2017). Metode Penelitian Pendidikan (Pendekatan Kuantitatif, Kualitatif Dan $R \& D$. Jakarta: Alfabeta.

Widoyoko, E. P. (2009). Evaluasi Program Pembelajaran. Jakarta: Pustaka Pembelajaran. Zubaedi. (2011). Desain Pendidikan Karakter. Jakarta:Kencana Prenada Media Group. 